\title{
Antimicrobial activity of bioactive compounds isolated from Swietenia mahagoni (L) Jacq. against Staphylococcus aureus and Pseudomonas aeruginosa
}

\author{
Handry Darussalam ${ }^{1 *}$, Titik Nuryastuti ${ }^{2}$, Mursiti ${ }^{3}$, Mustofa ${ }^{4}$ \\ ${ }^{1}$ Health Polytechnic of East Kalimantan, Minitry of Health, ${ }^{2}$ Department of Microbiology, \\ Faculty of Medicine, Universitas Gadjah Mada, Yogyakarta, ${ }^{3}$ Department of Chesmistry, \\ Universitas Negeri Semarang, Semarang, ${ }^{4}$ Department of Pharmacology and Therapy, Faculty \\ of Medicine, Universitas Gadjah Mada, Yogyakarta, Indonesia
}

\begin{abstract}
Widespread bacterial resistance has led to more difficult to treat infectious diseases with available antibiotics. Therefore, new antibiotics are needed face of the growing antibiotic resistance. Swietenia mahagoni (L.) Jacq. is one of potential medicinal plants as a source new antibiotics. Five compounds have been isolated from an ethanolic extract of S. mahagoni (L.) Jacq., however its antimicrobial activity has not been investigated, yet. This study was conducted to evaluate the antimicrobial activity of these compounds. Minimal Inhibitory Concentration (MIC) and Minimal Bactericidal Concentration (MBC) were determined against Staphylococcus aureus and Pseudomonas aeruginosa strains. Among five compounds tested, compound 3 (3,4,5,6,7-pentaethyl-1-methoxy-1H-indazole) and compound 4 (5-ethyl-6-methoxymethyl-2-methyl-1,2-dihydropyridine) were found to be active against the bactrial strains tested with the MICs and MBCs values ranged from 50 to $100 \mu \mathrm{g} / \mathrm{mL}$. In conclusion, among five compounds isolated from S. mahagoni (L.) Jacq., compound 3 and 4 showed moderate antimicrobial activity against $S$. aureus and $P$. aeruginosa strains.
\end{abstract}

\section{ABSTRAK}

Penyebaran secara luas resistensi bakteri menyebabkan pengobatan penyakit infeksi menjadi lebih sulit dengan antibiotik yang tersedia. Adanya antibiotik baru dengan demikian diperlukan menghadapi penyebaran resistensi antibiotik tersebut. Swietenia mahagoni (L.) Jacq adalah salah satu tanaman obat yang potensial sebagai penghasil antibiotik baru. Lima senyawa telah diisolasi dari ekstrak etanol biji S. mahagoni (L) Jacq. namun demikian aktivitas antimikrobanya belum dikaji. Penelitian ini bertujuan untuk mengkaji aktivitas antimikroba ke lima senyawa hasil isolasi tersebut. Kadar Hambat Minimal (KHM) dan Kadar Bunuh Minimal (KBM) ditetapkan terhadap strain Staphylococcus aureus and Pseudomonas aeruginosa. Diantaran lima senyawa yang diuji, senyawa $3(3,4,5,6,7$ pentaetil-1-metoksi-1H-indazol) dan 4 (5-etil-6-metoksimetil-2-metil-1,2-dihidropiridin) aktif terhadap strain bakteri yang diuji dengan nilai KHM dan KBM antara 50 sampai $100 \mu \mathrm{g} / \mathrm{mL}$. Dapat disimpulkan, diantaran lima senyawa yang diisolasi dari S. mahagoni (L.) Jacq. senyawa 3 dan 4 mempunyai aktivitas antimikroba moderat terhadap strain $S$. aureus and $P$. aeruginosa.

Keywords: Swietenia mahogany - active compounds - antimicrobial activity - Staphylococcus aureus - Pseudomonas aeruginosa

\footnotetext{
$\overline{\text { * corresponding author: handrybujangprabumulih@yahoo.co.id }}$
} 


\section{INTRODUCTION}

Infectious diseases still become a major health problem in developing and developed countries. They are leading cause of illness and death throughout the world. According to the Special Programme for Research and Training in Tropical Diseases, World Health Organization (TDRWHO), infectious diseases kill 3.5 million people annually, mostly the poor and young children who live in low and middle income in countries. ${ }^{1}$ Antibiotics are commonly used to treat of the infectious diseases. However, irrational use of antibiotics in the treatment of the diseases has led to the development of widespread bacterial resistance to antibiotics which becoming increasingly more difficult to treat the infectious diseases with currently available antibiotics. ${ }^{2}$ Face of growing antibiotics resistance, a strategy is needed to discover and develop new antibiotics. ${ }^{3}$

In the past few decades, the searh for new antimicrobial agents has occupied many research groups in the field of ethnopharmacology. Many medicinal plants from different part of the world have been studied. ${ }^{4}$ Swietenia mahagoni (L.) Jacq., locally known as the mahoni, belonging to the family Meliaceae, is one of potential medicinal plants as a source new antimicrobial agents that extensively investigated. The flower, leaf and bark extract of S. mahagoni (L.) Jacq. showed activity against Gram positive and Gram negative bacteria. ${ }^{5,6}$ Moreover, the seed extract $S$. mahagoni (L.) Jacq. was active against Bacillus subtillis, Sarcina lutea, Xanthomonas campestris, Klebsiella pneumoniae, and Escherichia coli. ${ }^{7}$

In order to find out new antimicrobial agents, five compounds have been isolated from an ethanolic extract of $S$. mahagoni (L.) Jacq. (FIGURE 1) included 7-hydroxy-2-(4-hydroxy3-methoxyphenyl)-chromen-4-one (compound 1), 3,6,7-trimethoxy-4-methyl-1,2,3,4tetrahydro-isoquinoline (compound 2), 3,4,5,6,7pentaethyl-1-methoxy-1H-indazole (compound 3), 5-ethyl-6-methoxymethyl-2-methyl-1,2dihydropyridine (compound 4) and 1,4-bis (3,4,5trimethoxy-phenyl)-tetrahydrofuro(3,4-c)furan (compound 5). In this study we reported the antimicrobial activity of these compounds against Staphylococcus aureus and Pseudomonas aeruginosa strains.

\section{MATERIALS AND METHODS}

\section{Bacterial strains}

The test bacteria employed in this study i.e. methicillin resistant $S$. aureus (MRSA), S. aureus (ATCC 25923), P. aeruginosa clinical isolate, and $P$. aeruginosa (ATCC 27853) were obtained from the Department of Microbiology, Faculty of Medicine, Universitas Gadjah Mada, Yogyakarta. These bacterial strains were maintained in viable state via inoculation on Brain Heart Infusion Double Strength (BDHI DS) media and overnight incubation at $37^{\circ} \mathrm{C}$.

\section{Tested compounds}

The tested compounds were isolated from an ethanolic extract of S. mahagoni (L.) Jacq. seed by Dra. Mursiti, MSi. from the Department of Chemistry, Universitas Negeri Semarang. The structure of these tested compounds are presented in FIGURE 1. 
<smiles>CO[C@H]1CC(C2CC(O)C3=C(CC(O)CC3)O2)CC[C@@H]1O</smiles>

7-hydroxy-2-(4-hydroxy-3methoxyphenyl)-chromen-4-one (compound 1)<smiles>CCC1CCN(CC)C2C(CC)C(C)C(CC)C1C2CC</smiles>

3,4,5,6,7-pentaethyl-1-methoxy$1 \mathrm{H}$-indazole (compound 3 )

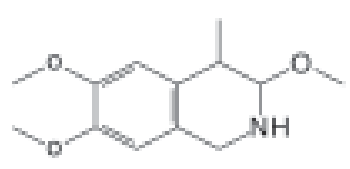

3,6,7-trimethoxy-4-methyl-1,2,3,4tetrahydro-isoquinoline (compound 2)<smiles>CCC1=C(OC)NC(C)CC1COC</smiles>

5-ethyl-6-methoxymethyl-2-methyl1,2-dihydropyridine (compound 4)

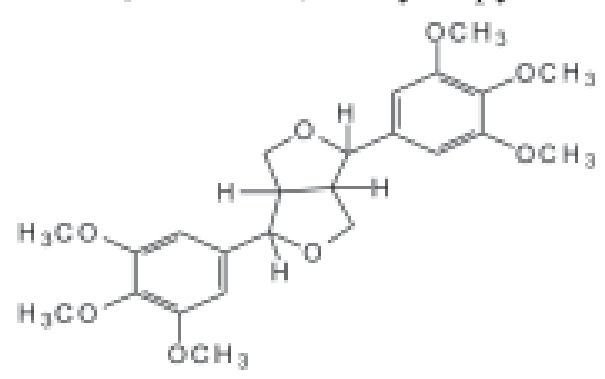

\section{1,4-bis(3,4,5-trimethoxy-phenyl)-tetrahydrofuro(3,4-c)furan (compound 5)}

FIGURE 1. Tested compounds isolated from from an ethanolic extract of S. mahagoni (L.) Jacq. seed

\section{Antimicrobial activity determination}

Minimal Inhibitory Concentration (MIC) determination. The MIC of tested compounds was determined using the tube dilution method. Bacterial colonies were picked from freshly culture plates and diluted with Brain Heart Infusion Double Strength (BDHI DS) media to final concentration of $10^{6} \mathrm{CFU} / \mathrm{mL}$. Serial dilution of the tested compounds ranged from 1.56 to $800.00 \mu \mathrm{g} / \mathrm{mL}$ were prepared by diluting the stock solution with BHI DS media. One $\mathrm{mL}$ of the diluted bacterial suspension was added to tube containing one $\mathrm{mL}$ of serial the tested compounds dilution to yield the appropriate density $5 \times 10^{5} \mathrm{CFU} / \mathrm{mL}$. The tubes were then incubated for $24 \mathrm{~h}$ at $37^{\circ} \mathrm{C}$. As negative control was a tube containing the diluted bacterial suspensions without the tested compounds, whereas as positive control was a tube containing the diluted bacterial suspensions with levofloxacin. The MICs were defined as the lowest concentration of the tested compounds that completely inhibits the growth of the organism as detected by the unaided eye. All MIC determination were conducted three times on independent experiments.

Minimal Bactericidal Concentration (MBC) determination. The bactericidal activities of the tested compounds were determined on the methicillin resistant $S$. aureus and P. aeruginosa clinical isolates. The suspentions of all the macroscopically clear tubes were inoculated onto plates of blood agar and were then incubated for 
$24 \mathrm{~h}$ at $37^{\circ} \mathrm{C}$. As control was a tube containing sterile distilled water and no the tested compounds were included. At the end of the incubation, the number of bacteria was counted in each of the tubes and was compared with the number of bacteria of the control tube. The MBCs were defined as the lowest concentration giving $0.1 \%$ bacterial survival. $^{8}$

\section{RESULTS}

Antimicrobial activity of the tested compounds was investigated in vitro against Gram positive bacteria [MRSA and S. aureus (ATCC 25923)] and Gram negative bacteria [P. aeruginosa clinical isolate and P. aeruginosa (ATCC 27853)]. The antimicrobial activity was expressed by MICs and MBCs. The MICs values of the tested compounds are presented in TABLE 1 . Among the five tested compounds, two compounds i.e. compound 3 and 4 showed antimicrobial activity against the bacterial strains tested. The compound 3 showed highest activity against $P$. aeruginosa (ATCC 27853) strain with the MIC value of $50 \mu \mathrm{g} / \mathrm{mL}$, whereas the compound 4 showed highest activity against both S. aureus (ATCC 25923) and P. aeruginosa (ATCC 27853) strains with the MICs values of $50 \mu \mathrm{g} / \mathrm{mL}$. However, the MICs of the compound $\mathbf{3}$ and $\mathbf{4}$ were lower than the MIC of levofloxacin $(1-4 \mu \mathrm{g} / \mathrm{mL})$ as positive control.

TABLE 1. The MICs values ( $\mu$ ìg/mL) of tested compounds against the bacterial tested

\begin{tabular}{|c|c|c|c|c|}
\hline \multirow[b]{2}{*}{ Compound } & \multicolumn{4}{|c|}{ Bacterial strain } \\
\hline & MRSA & $\begin{array}{l}S \\
\text { aureus } \\
\text { ATCC }\end{array}$ & $\begin{array}{l}P . \\
\text { aerzeginasa } \\
\text { isolate }\end{array}$ & $\begin{array}{l}P . \\
\text { aeruginosd } \\
\text { ATCC }\end{array}$ \\
\hline Compound 1 & NA & NA & $\mathrm{NA}$ & NA \\
\hline Compound 2 & NA & NA & $\mathrm{NA}$ & NA \\
\hline Compound 3 & 200 & 100 & 100 & 50 \\
\hline Compound 4 & 100 & 50 & 100 & 50 \\
\hline Compound 5 & NA & NA & NA & NA \\
\hline Levofloxacin & 1 & 1 & 4 & 4 \\
\hline
\end{tabular}

NA: non activity against bacterial tested

The MBCs values of the tested compounds are presented in TABLE 2 . The MBCs values of the compound 3 and $\mathbf{4}$ were similar with its MICs values. The MBCs of these two compounds were also lower than the MBCs of the levofloxacin ((1 $-4 \mu \mathrm{g} / \mathrm{mL})$.

TABLE 2. The MBCs values (ìg/mL) of tested compounds against the bacterial tested

\begin{tabular}{lcccc}
\hline \multirow{2}{*}{ Compound } & \multicolumn{4}{c}{ Bacterial strain } \\
\cline { 2 - 5 } & MRSA & S. aureus ATCC & $P$. aeruginasa isolate & $P$. aeruginosa ATCC \\
\hline Compound 1 & NA & NA & NA & NA \\
Compound 2 & NA & NA & NA & NA \\
Compound 3 & 200 & 100 & 100 & 50 \\
Compound 4 & 100 & 50 & 100 & 50 \\
Compound 5 & NA & NA & NA & NA \\
Levofloxacin & 1 & 1 & 4 & 4 \\
\hline
\end{tabular}

ND: no activity against bacterial tested 


\section{DISCUSSION}

Various parts of Swietenia mahagoni (L.) Jacq. have been used traditionally for the treatment of hypertension, diabetes, malaria, amoebiasis, coughs, tuberculosis, antiseptic, astringent, diarrhea, and tonic. ${ }^{9-11}$ Swietenia mahagoni (L.) Jacq. seeds are also reported to have medicinal value for the treatment of hypertension, diabetes, malaria, ${ }^{12}$ cancer, amoebiasis, coughs and intertinal parasitism. ${ }^{13}$ Furthermore, the seed extract $S$. mahagoni (L.) Jacq. have been accounted to possess antimicrobial activity. ${ }^{7}$

In these study we have tested the antimicrobial activity of five compounds isolated from $S$. mahagoni (L.) Jacq. Among the five compounds tested, two compounds i.e. compound $\mathbf{3}$ and $\mathbf{4}$ showed antimicrobial activity against $S$. aureus and $P$. aeruginosa strains tested with the MICs and MBCs values ranged from 50 to $100 \mu \mathrm{g} / \mathrm{mL}$. The MICs and MBCs values of these compound 3 and 4 were lower than the MICs and MBCs values of levofloxacin (1-4 $\mu \mathrm{g} / \mathrm{mL})$ as positive control indicating the antimicrobial activity of these compounds were moderate.

Some bioactive compounds have been isolated from S. mahagoni (L) Jacq. and their antimicrobial activity has been investigated. Kader et al. ${ }^{7}$ isolated two limonoids, swietenine and 3$O$-tigloylswietenolide from the chloroform soluble fraction of an ethanolic extract of S. mahagony (L) Jacq. seeds and evaluated its antimicrobial activity against a series of Gram positive and Gram negative bacteria. The most potent antimicrobial activity of these compounds were against $B$. megatorium and E. coli. Ghosh et al. ${ }^{14}$ isolated other limonoids i.e. swietenolide and 2-hydroxy3-O-tigloylswietenolide and also evaluated its antimicrobial activity against eight multiple-drugresistant bacterial strains including Gram positive and Gram negative bacteria. 2-Hydroxy-3-Otigloylswietenolidehad, overall, more potent activity than swietenolide. The most potent antibacterial activity of swietenolide was against Haemophilus influenzae, Salmonella typhi, and Salmonella paratyphi, and 2-hydroxy-3-O-tigloylswietenolide was most active against Streptococcus pneumoniae, Salmonella typhi, and Salmonella paratyphi. Both the compounds were least effective against Klebsiella pneumoniae.

Both of the compound $3(3,4,5,6,7$ pentaethyl-1-methoxy-1H-indazole) and compound 4 (5-ethyl-6-methoxymethyl-2methyl-1,2-dihydropyridine) are a class of alkaloids which are well known for their wide range of pharmacological activities including antimicrobial activity. ${ }^{15,16}$ Although the antimicrobial activity of the compound 3 and compound 4 were found to be moderate, however the antimicrobial activity of these compounds have not been reported, yet. Therefore, these compounds could be used as starting points for new antimicrobial discovery.

\section{CONCLUSION}

In conclusion, among five compounds isolated from S. mahagoni (L.) Jacq., compound 3 (3,4,5,6,7-pentaethyl-1-methoxy-1H-indazole) and compound 4 (5-ethyl-6-methoxymethyl-2methyl-1,2-dihydropyridine) showed moderate antimicrobial activity against $S$. aureus and $P$. aeruginosa.

\section{ACKNOWLEDGEMENTS}

The authors would like to thank all technicians from Department of Microbiology, Faculty of Medicine, Universitas Gadjah Mada for all valuable assisstances during the study.

\section{REFERENCES}

1. TDR|Global Report for Research on Infectious Diseases, WHO. 2014. [serial online] [cited April 8, 2014]. Available from: http://www.who.int/tdr/ capacity/global_report/en/

2. de J Sosa A, Byarugaba CF, Amábile-Cuevas CF, Hsueh PR, Kariuki S, Okeke IN, editors. 
Antimicrobial resistance in developing countries. New York: Spinger, 2010.

3. Vashistha VM. Growing antibiotics resistance and the need for new antibiotics. Indian Pediatr 2010; 47:505-6.

4. Ríos JL and Recia MC. Medicinal plants and antimicrobial activity. J Ethnopharmacol 2005; 100(1-2):80-4.

5. Rahman SMA, Akter M, Hira TE, Mian MY, Ahmed I, Rahman MM. Antioxidant and antimicrobial activities of flower and bark extract of Swietenia mahagoni (L.) Jacq. JPP 2014; 2(6):185-8.

6. Haque M, Ullah MO, Nahar K. In vitro antibacterial and cytotoxic activities of different parts of plant Swietenia mahagony. Pakistas J Biol Sci 2009; 12(7):599-602.

7. Alam K, Mansur FJ, Karim MM, Haque A. Antimicrobial activity of Swietenia mahagoni (seed) against various pathogenic microbes. Indo Am J Pharm Res 2014; 4(05):2362-6.

8. Cannilac $\mathrm{N}$ and Mourey A. Antibacterial activity of the essential oil of Picea excelsa on Listeria, Staphylococcus aureus and coliform bacteria. Food Microbiol 2001; 18: 261-8.

9. Shahidur Rahman AKM, Azad Chowdhury AK, Husne-Ara A, Sheikh ZR, Mohammad SA, Lutfun $\mathrm{N}$, et al. Antibacterial activity of two limonoids from Swietenia Mahagoni against multiple-drugresistant (MDR) bacterial strains. J Nat Med 2009; 63: 41-5.
10. Chen Y, Wang X, Fan C, Yan S, Yue J. Swiemahogins A and B, two novel limonoids from Swietenia mahogany. Tetrahedron Lett 2007; 48(42):7480-4.

11. Bhurat MR, Bavaskar SR, Agrawal AD, Bagad YM. Swietenia mahagoni Linn. - a phytopharmacological review. Asian J Pharm Res 2011; (1):1-4.

12. Nagalakshmi MAH, Thangadurai D, Rao DM, Pullaiah T. Phytochemical and antimicrobial study of Chukrasia tabularis leaves. Fitoterapia 2001; 72:62-4.

13. Bacsal K, Chavez L, Diaz I, Espina S, Javillo J, Manzanilla $\mathrm{H}$, et al. The effect of Swietenia mahogani (Mahogany) seed extract on indomethacin-induced gastric ulcers in female Sprague- Dawley rats. Acta Med Philippina 1997; 3:127-39.

14. Ghosh S, Besra SE, Roy K, Gupta JK, Vedasiromoni JR. Pharmacological effects of methanolic extract of Swietenia mahagoni Jacq (Meliaceae) seeds. Int Green Pharm. 2009;3(3): 206-10.

15. Singh A, Duggal S, Kaur N, Singh J. Berberine: alkaloid with wide spectrum of pharmacological activities. J Nat Prod 2010; 3:64-75.

16. Patel K, Gadewar M, Tripathi R, Prasad SK, Patel DK. A review on medicinal importance, pharmacological activity and bioanalytical aspects of beta-carboline alkaloid from mahoga. Asian Pac J Trop Biomed 2012; 2(8): 660-4. 